\title{
Body Weight-Length Relationships in Giant Otters (Pteronura brasiliensis) (Carnivora, Mustelidae)
}

\author{
Fernando César Weber $\operatorname{Rosas}^{1 *}$, Carla Soares da Rocha ${ }^{1}$, Gália Ely de Mattos ${ }^{1}$ and Stella \\ Maris Lazzarini ${ }^{2}$
}

${ }^{1}$ Instituto Nacional de Pesquisas da Amazônia; Laboratório de Mamíferos Aquáticos; C.P.: 478; 69011-970; Manaus - AM - Brasil. ${ }^{2}$ Centro de Pesquisa e Preservação de Mamíferos Aquáticos; Manaus Energia S.A.; Vila de Balbina; 69736-000; Presidente Figueiredo - AM - Brasil

\begin{abstract}
Few giant otters (Pteronura brasiliensis) have been measured and weighed and its actual size is controversial in the literature. This study presents the weight-length relationship of Amazonian giant otters using 15 captive individuals. The maximum length and weight were $163 \mathrm{~cm}$ and $22.5 \mathrm{~kg}$, and $162 \mathrm{~cm}$ and $28.8 \mathrm{~kg}$, for the males and females, respectively. The weight-length relationships were not significantly different between the sexes $(t=0.658, d . f .=11$, $P>0.05)$ and can be expressed by the equation: $W=1.48 \times 10^{-5} L^{2.81}$. Considering that some of the giant otters used in this study were old individuals (more than 10 years old), and that all the animals analyzed were healthy, it is possible to assume that the weight-length relationships obtained are probably a close approximation of the relationship of giant otters of the Amazon region and can be used by institutions that keep this species in captivity as a base to quickly assess the animal's nutritive status.
\end{abstract}

Key words: Giant otters, Pteronura brasiliensis, biometry, Amazonia, threatened species

\section{INTRODUCTION}

The giant otter, Pteronura brasiliensis (Zimmermann, 1780), is a semi-aquatic mammal belonging to the Mustelidae family, and is currently classified as "endangered" by IUCN (2009). It is a medium-sized mammal and is considered to be the largest representative of the otter group. Giant otters have an elongated body, short legs, a robust and flattened head, small and rounded ears, and webbed feet (Carter and Rosas, 1997; Rosas, 2004). The difficulty in handling this species in order to carry out biometry on captive animals without anesthesia and the small number of giant otters which have been measured and weighed, have jeopardized the accuracy in obtaining the total length and weight reached by $P$. brasiliensis. Due to this, field biologists have recently requested information on adult body length and corresponding weights and sexes of giant otter (Sykes-Gatz, 2005).

If well adjusted, the weight-length relationship of a species can contribute to a better understanding of its biology, providing information about the condition factor of the individuals and contributing towards its management and conservation. In this context, the aim of the present study was to determine the weight-length relationship of Amazonian giant otters, and discuss the total length and maximum weight reached by the species in the Amazon.

\footnotetext{
*Author for correspondence: frosas@inpa.gov.br
} 


\section{MATERIAL AND METHODS}

Biometric data of 15 giant otters (11 males and 4 females) which had been kept in captivity at the Aquatic Mammals Laboratory of the National Institute of Amazonian Research (LMA/INPA) and the Research and Preservation Center of Aquatic Mammals of Manaus Energia S.A. (CPPMA/Manaus Energia S.A.) at Balbina hydroelectric power station between 1982 and 2004 were used. The ages of the animals studied varied from calves (less than one year old) to mature animals that had been in captivity for over 10 years. All animals studied came from the Amazon basin region and were healthy at the time they were measured and weighed. All biometric data were obtained with the animals anesthetized. The weight was obtained using a scale with a capacity of $50 \mathrm{~kg}$ (accuracy of $200 \mathrm{~g}$ ) and the total length was recorded in a straight line from the tip of the snout to the tip of the tail, following the methodology recommended by the Action Plan of Brazilian Aquatic Mammals (IBAMA, 2001).

The weight-length relationships were calculated for the sexes separately and expressed by the following equation:

$$
W=\phi L^{\theta} \quad(\text { Santos, 1978) }
$$

where,

$W=$ total body weight $(\mathrm{kg})$

$L=$ total body length $(\mathrm{cm})$

$\phi=e^{a}$

$\theta=b$ $a$ and $b=$ parameters of the linear regression of the weight-length relationship obtained by the least square method after logarithmic transformation of the weight and length data. Letter " $a$ " represents the $y$-intercept and letter " $b$ " the regression coefficient or slope.

\section{$e=$ base of the natural logarithm}

The linear regression slopes of the males and females obtained after logarithmic transformation of weight and length data were compared using a Student's $t$-test with a significance level of 0.05 (Zar, 1999).

\section{RESULTS}

The largest male and female measured had total lengths of $163 \mathrm{~cm}$ and $162 \mathrm{~cm}$, respectively, and the maximum weights observed were $22.5 \mathrm{~kg}$ for the males and $28.8 \mathrm{~kg}$ for the females.

The linear regression equation obtained after the logarithmic transformation of the weight and length data was

$\log W=-10.70+2.71 \log L\left(\mathrm{r}^{2}=0.983\right)$ for males, and $\log W=-12.58+3.12 \log L \quad\left(r^{2}=0.955\right)$ for females.

The result of the $t$-test analysis comparing the regression coefficient (slope) of the best fit lines obtained for the males and females did not reveal any significant differences between them $(t=$ 0.658 , d.f. $=11, P>0.05)$. Therefore, the linear regression equation was adjusted for both the sexes (Fig. 1), and the allometric curve of weightlength relationship (Fig. 2) was expressed by the equation $W=1.48 \times 10^{-5} L^{2.81}$.

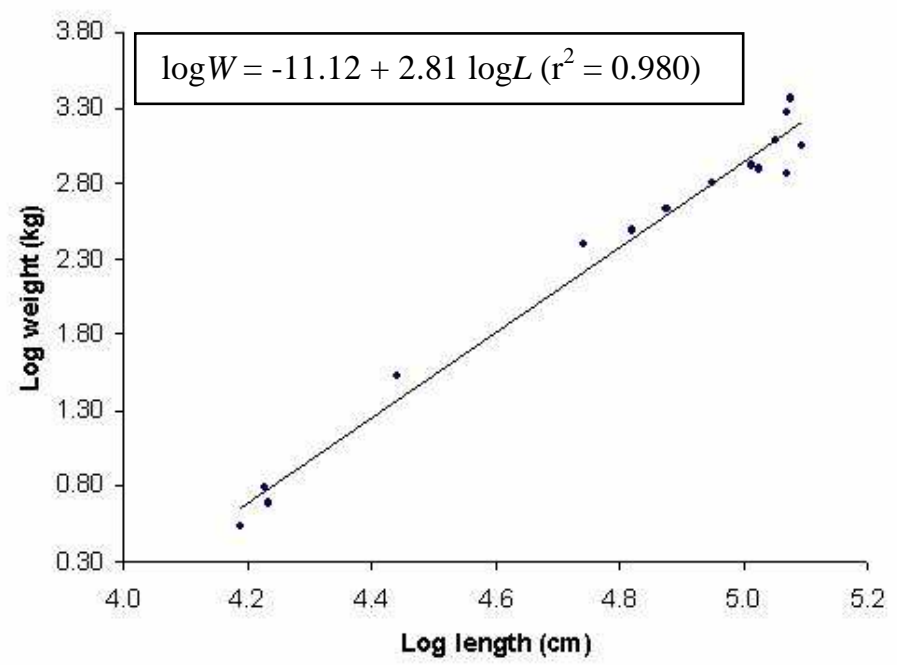

Figure 1 - Scatter plot of log weight $(W)(\mathrm{kg})$ on log length $(L)(\mathrm{cm})$ of captive Amazonian giant otters. 


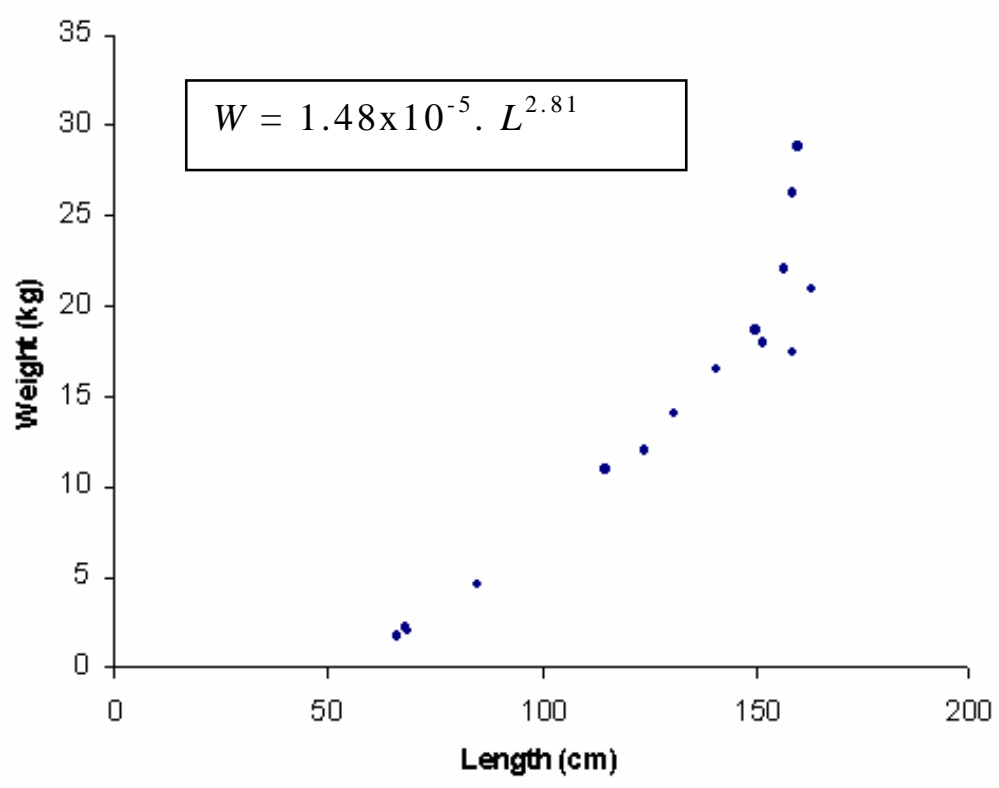

Figure 2 - Scatter plot of weight $(W)(\mathrm{kg})$ on length $(L)(\mathrm{cm})$ of captive giant otters from the Amazon basin.

\section{DISCUSSION}

Despite being a threatened species (IUCN, 2009), the total length and weight of giant otters are still controversial. The maximum lengths recorded in this study were approximately 5 and $9.5 \%$ smaller for the females and males, respectively, when compared with the largest length values presented by Duplaix (1980). However, giant otter weight and length data presented in the literature were at best tentative, and the actual size of $P$. brasiliensis has been raising much speculation (Duplaix, 1980). Regarding the weight, the maximum value observed for the males $(22.5 \mathrm{~kg})$ was approximately $30 \%$ less than that mentioned in the literature, whereas the maximum value for the females $(28.8 \mathrm{~kg})$ was approximately $11 \%$ greater. It is possible that these differences are due to variations in the way the animals were measured and in the accuracy when weighing the individuals. However, the discrepancies encountered in the weight and length values, when compared with those mentioned in the literature, could also be due to populational differences. According to Harris (1968), there are two distinct giant otter sub-species: 1) Pteronura brasiliensis brasiliensis, distributed in the Amazon basin, and 2) Pteronura brasiliensis paranensis, occurring in the Paraguay and Paraná river basins (Pantanal region). Apparently, one of the characteristics that distinguishes the two sub-species is the smaller body size of $P$. b. paranensis (Harris, 1968). However, no accurate body size data are available in the literature to confirm this statement. Additionally, the validity of these two sub-species needs to be scientifically confirmed (Duplaix, 1980; Carter and Rosas, 1997). According to Garcia et al. (2007), mitochondrial DNA analyses indicated some degree of geographic correlation and a high level of inter-population divergence in $P$. brasiliensis from the Amazon and Pantanal regions. However, the sub-species division is not highly supported and a larger number of individuals must be genetically analyzed. In any case, the maximum total length value of $2.4 \mathrm{~m}$ presented by Harris (1968) included measurements obtained from skins and by different observers without precise descriptions of how they were obtained. According to Carter and Rosas (1997), skin measurements are probably not representative of standard body lengths due to distortions during skin preparations. Additionally, it is probable that most of the measurements obtained directly from the animals (not from the skins) in the beginning of the $19^{\text {th }}$ century referred to the curvilinear length (following the body's curves) (Harris, 1968). These lengths can vary considerably and individuals with the same standard length can have 
different curvilinear lengths depending on their nutritional status. Invariably, curvilinear lengths are always longer than total body lengths measured in a straight line (standard length). Taking into consideration the fact that the giant otters analyzed in this study came from different regions of the Amazon basin, including animals from the upper Negro River, upper Solimões River, and middle Amazon River, and that they were measured in a standardized way from tip to tip, it can be assumed that maximum lengths and weights obtained in this study are probably a good approximation of the asymptotic length and weight values reached by the species in the Amazon. According to the present data, it is probable that the maximum length and weight of giant otters in Amazonia are not greater than $1.80 \mathrm{~m}$ and $30 \mathrm{~kg}$, respectively.

Weight can be best used as a growth indicator when it is combined with body measurements. A continuous follow-up of total length and weight can be used as indicators of an increase in weight and length, thereby providing a better description of the animal, which will reflect the characteristics of the species and its nutritive status (Perrin et al., 2005).

According to Duplaix (1980), P. brasiliensis females are slightly smaller than the males. However, the length and weight data presented in the literature were tentative and it is necessary to study a larger number of animals to confirm this statement. The difficulty in handling giant otters in order to obtain biometric data is the main problem when achieving accurate weight and length measurements. An alternative method to obtain total length measurements of captive giant otters has been described by Rosas et al. (2006), which can help different institutions that keep this species in captivity to measure a larger number of individuals.

In the present study it was observed that, contrary to what was mentioned by Duplaix (1980), the females had greater absolute weights than the males, while the total lengths were similar for both the sexes. However, despite the weight differences, the absence of a significant difference in the slope of the weight and length regressions of the males and females, suggests that there is no difference between the sexes and allowed for the calculation of a single equation to express the weight-length relationship of Amazonian giant otters.
It is necessary, however, to keep in mind that all the giant otters analyzed in this study were captive, which could result in fatter animals due to the limitation of physical activities imposed by captivity. This could have happened with the females, which were $11 \%$ heavier in this study compared with the values mentioned by Harris (1968) and Duplaix (1980). However, it certainly did not apply to the males, which were up to $30 \%$ lighter than the maximum values mentioned in the literature. Therefore, considering that there were no significant differences between the male and female body weight-length relationships, and that the giant otters here analyzed were healthy and measured and weighed with accuracy, the results presented suggest that the weight-length equations obtained are probably close to that of free-range giant otters of the Amazon region. As recommended by McBain (2001) and Perrin et al. (2005), in husbandry the condition of a captive animal can be assessed by comparing its weight with normative values at length in healthy animals. Therefore, the relationship expressed by the equation $W=1.48 \times 10^{-5} L^{2.81}$ can be used by those institutions that keep giant otters in captivity as a base to quickly assess the animal's nutritive status.

\section{ACKNOWLEDGEMENTS}

We thank the veterinarian José Anselmo d'Affonseca Neto and the PREVET staff in helping us to anesthetize the giant otters. Kesä K. Lehti revised the English version of the manuscript. We also thank Philadelphia Zoo (USA) for partial financial support.

\section{RESUMO}

Poucas ariranhas (Pteronura brasiliensis) foram medidas e pesadas com precisão, e seu comprimento e peso máximos ainda são controversos na literatura. Neste estudo apresentamos a relação peso/comprimento da ariranha da Amazônia usando 15 animais de cativeiro. $\mathrm{O}$ comprimento e peso máximos observados foram $163 \mathrm{~cm}$ e $22,5 \mathrm{~kg}$, e $162 \mathrm{~cm} \mathrm{e}$ $28,8 \mathrm{~kg}$, para machos e fêmeas, respectivamente. As relações peso/comprimento não foram significativamente diferentes entre os sexos $(t=$ $0,658, d . f .=11, P>0,05)$ e podem ser agrupadas e 
expressas por uma única equação $P=1,48 \times 10^{-5}$ $C^{2,81}$. Considerando que algumas das ariranhas usadas neste estudo eram indivíduos velhos (com mais que 10 anos de idade) e que todos os animais analisados eram saudáveis, acredita-se que os resultados apresentados forneçam uma boa aproximação da relação peso/comprimento de ariranhas de vida livre da região Amazônica e podem ser utilizados por instituições que mantêm esta espécie em cativeiro para acessar o status nutricional dos animais.

\section{REFERENCES}

Carter, S.K. and Rosas, F.C.W. (1997), Biology and conservation of the giant otter Pteronura brasiliensis. Mammal Review, 27, 1-26.

Duplaix, N. (1980), Observations on the ecology and behavior of the giant river otter Pteronura brasiliensis in Suriname. Revue Ecologique (Terre Vie), 34, 495-620.

Harris, C.J. (1968), Otters. A study of the recent Lutrinae. Weidenfeld and Nicolson. London, United Kingdom.

Garcia, D.M.; Marmontel, M.; Rosas, F.C.W. and Santos, F.R. (2007), Conservation genetics of the giant otter (Pteronura brasiliensis (Zimmermann, 1780)) (Carnivora, Mustelidae). Brazilian Journal of Biology, 67 (4, Suppl.), 819-827.

IBAMA. (2001), Mamíferos aquáticos do Brasil: Plano de ação. Versão II. 2nd ed. Instituto Brasileiro do Meio Ambiente e dos Recursos Naturais Renováveis. Brasília, Brasil.
IUCN. (2009). IUCN Red List of Threatened Species. Version 2009.1. IUCN, Gland, Switzerland <WWW.iucnredlist.org>. Downloaded on 29 May 2009.

McBain, J.F. (2001), Cetacean medicine. In- CRC Handbook of marine mammals medicine ed. L.A. Dierauf and F.M.D. Gulland. CRC Press, Boca Raton, Florida. pp. 895-906.

Perrin, W.F.; Dolar, M.L.L. and Chan, C.M. (2005), Length-weight relationships in the spinner dolphin (Stenella longirostris). Marine Mammal Science, 21,765-778.

Rosas, F.C.W. (2004), Ariranha, Pteronura brasiliensis (Carnivora: Mustelidae). In- História natural, ecologia e conservação de algumas espécies de plantas e animais da Amazônia, ed. R. Cintra. EDUA/INPA/ FAPEAM, Manaus, Brasil. pp. 265269.

Rosas, F.C.W.; da Rocha, C.S. and de Mattos, G.E. (2006), A method to measure captive giant otters (Pteronura brasiliensis) without sedation. The Latin American Journal of Aquatic Mammals, 5(1), 65-66.

Santos, E.P. (1978), Dinâmica de populações aplicada à pesca e piscicultura. Editora da Universidade de São Paulo, São Paulo, Brasil.

Sykes-Gatz, S. (2005), International Giant Otter Studbook. Zoologischer Garten Dortmund, Germany.

Zar, J.H. (1999), Biostatistical analysis. 4th ed. Prentice Hall, Upper Saddle River. New Jersey.

Received: December 27, 2006; Revised: May 25, 2007; Accepted: July 16, 2008. 